\title{
Ethno-religious socialisation, national culture and the social construction of British Muslim identity
}

\author{
Riyaz Timol $^{1}$ (1)
}

Accepted: 23 September 2020/Published online: 7 November 2020

(C) The Author(s) 2020

\begin{abstract}
This paper interfaces a specific theory of socialisation, derived from Peter Berger and Thomas Luckmann's influential book The Social Construction of Reality, with the empirical story of Muslim settlement in Britain. It makes a key distinction between the primary socialisation experiences of immigrants, which unfolded in their countries of origin, and that of their diaspora-born offspring whose identity is forged between an inherited ethno-religious culture and the wider British collective conscience. Drawing on extensive ethnographic fieldwork conducted with the Islamic revivalist movement Tablighi Jama'at, the paper explores the cultural embodiments of religion as it evolves over generations through an examination of identity markers such as language, dress and food. The analysis triangulates Berger and Luckmann's concepts of primary and secondary socialisation with a tripartite model of British Muslim identity developed by Ron Geaves. It further argues, in light of Kwame Gyekye's theory of nation-building, that recent government efforts to promulgate a set of fundamental British values in schools represent an essentially Durkheimian attempt to supply the 'social glue' that binds citizens together. While the article acknowledges the increasing salience of religion for many British-born Muslims, it argues for the ongoing influence of ethnicity and nationality in determining their lived experience.
\end{abstract}

Keywords British Muslim identity · Intergenerational transmission · Religious socialisation · Muslims in Britain · Sociology of knowledge · Berger \& Luckmann · Ethnoreligious identity

Riyaz Timol

TimolR1@ cardiff.ac.uk

1 Centre for the Study of Islam in the UK, School of History, Archaeology and Religion, Cardiff University, John Percival Building (5.49B), Colum Drive, Cardiff CF10 3EU, UK 


\section{Introduction}

In their influential treatise on the sociology of knowledge, Peter Berger and Thomas Luckmann (1966) postulate a triangular dynamic in which human social experience is mediated with reference to three distinct processes. First, meanings are continually produced and externalised through a perpetual motor of inescapable human activity. Secondly, they are objectivated as they sediment into institutions and traditions which reify over time into entities sui generis - constellations of monolithic meaning that impose themselves upon groups of human actors; though, crucially, they remain dependent upon those same human actors for their ongoing production. Lastly, they are internalised through ongoing processes of socialisation in which the now taken-forgranted suppositions of the culture in question penetrate the subjective consciousness of new generations of children or newcomers to the social order who, in the case of thoroughly socialised individuals, can imagine no other way of being. This tripartite conceptualisation has its roots in the origins of sociology as such and attempts a synthesis between classical Durkheimian notions of the objective facticity of society and Weber's contrary emphasis on Verstehen. Though the above theoretical system was developed in reference to a generic sociology of knowledge, Berger (1967) later applied it specifically to religion, transforming the 'symbolic universe' advanced in his work with Luckmann into The Sacred Canopy.

Drawing on this theoretical model, this paper proposes a framework for understanding the social construction of British Muslim identity. It particularly focusses on Berger and Luckmann's third process, namely that of internalisation through means of both 'primary' and 'secondary' socialisation into a given Weltanschauung. Socialisation is defined as follows:

...the comprehensive and consistent induction of an individual into the objective world of a society or a sector of it. Primary socialization is the first socialization an individual undergoes in childhood, through which he becomes a member of society. Secondary socialization is any subsequent process that inducts an already socialized individual into new sectors of the objective world of his society. (Berger and Luckmann 1966, p. 150)

The latent power of socialisation thus depends upon the existence of social worlds whose meanings have already sedimented into tradition through prior processes of externalisation and objectivation and which impose themselves - with differing levels of intensity - upon human consciousness as external facticity. These worlds of meaning, however, are radically different between societies, in terms of both their substantive content and their cultural expressions. This is significant when considering the socialisation experiences of immigrants and their offspring. This paper therefore interrogates the intersection of a specific theory of socialisation with the empirical story of Muslim settlement in Britain. It makes a key distinction between the primary socialisation experiences of immigrants, which unfolded in their countries of origin, and that of their diaspora-born offspring whose identity is forged between an inherited ethno-religious culture and the wider British collective conscience. By deploying a sociological approach, the paper does not focus on intellectual or theological attempts 
to reconcile Islam with Western modernity (as exemplified, say, in the works of Tariq Ramadan or Khaled Abou El Fadl), but rather captures an on-the-ground cultural efflorescence through a fine-grained ethnographic lens. While Berger and Luckmann's work has been one of the most influential in twentieth century sociology, ${ }^{1}$ this paper - to the author's knowledge - is the first application of it to theorise the construction of immigrant and post-immigrant identity in a specific religious minority group.

The paper arises inductively out of ethnographic fieldwork conducted with the British branch of the international Islamic revivalist movement, the Tablighi Jama'at (TJ). My specific concern in this fieldwork was to examine intergenerational transmission within male members of the movement in Britain. The longevity of the movement's presence in the UK, its appeal to multiple generations of British Muslims and the distinct nature of its mosque-based activism which brings 'elders' and 'youngsters' together in a closed space makes it a particularly useful case study of intergenerational transmission. A total of 59 interviews were conducted with both first-generation migrants and their British-born counterparts. These spanned a spectrum of experience from seasoned veterans, with decades of devoted TJ service, to occasional youthful participants, ex-members and critics. As part of my fieldwork, I also participated in a wide range of Tablighi activities. This included, most significantly, joining numerous khuruj outings - a term which refers to the movement's emblematic mosque-based retreats - that saw me travel to various towns and cities in the UK and undertake a prolonged 42-day road trip to Bulgaria with a British TJ group. While the paper draws upon data generated during these fieldwork experiences, the theoretical infrastructure it proposes seeks to transcend them by undergirding British Muslim identity more generally. As such, the paper is squarely located in the sociology of Muslim communities in Britain.

The paper consists of seven sections. In the first, I elaborate in generic terms ways in which religious identities are transmitted to children through the process of "primary socialisation' and explore why intergenerational transmission of Islam in the UK has been more successful than other religions. In the second, I deploy Durkheim to sketch some contours of a contemporary British 'collective conscience'-with specific reference to declining national and religious identities and a rising tide of individualisation - which underpins heterogeneous spheres of society in which processes of 'secondary socialisation' unfold. In the third, I apply the processes of primary and secondary socialisation to the horizontal immigration of Muslims into Britain, and distinguish their experiences from that of Western converts, by triangulating Berger and Luckmann's work with Ron Geaves' conceptual distillation of British Muslim identity into the discrete categories of ethnicity, religion and nationality. In the fourth, fifth and sixth sections, I examine the vertical transmission of an ethno-religious Muslim identity across generations in Britain through an ethnographic exploration of cultural identity markers such as language, food and dress; and also explicate the sociological mechanics through which 'intra-religious conversion' occurs among TJ neophytes. Lastly, drawing upon Kwame Gyekye's theory of nation-building, I interpret the British government's enunciation of a set of fundamental British values to be mandatorily

\footnotetext{
${ }^{1}$ See, for instance, the 2016 special issue of the journal Cultural Sociology which celebrated the book's fiftieth anniversary.
} 
enacted in schools as an essentially Durkheimian attempt - especially in light of the widespread fracturing of national and religious identities - to supply the 'social glue' that binds citizens together. The paper concludes that British Muslim identity should best be viewed as a cultural mélange or disorderly bricolage that draws simultaneously from multiple sources and which manifests differently under the pressure of different situations.

\section{Primary socialisation and Muslim nurture}

Primary socialisation is the key process through which a child attains a self-conception of identity and learns to behave in the world. It massively and decisively determines the development of subjective consciousness since it is administered through the emotionally charged medium of 'significant others', usually parents, who necessarily develop strong bonds of intimacy with the growing child. ${ }^{2}$ In the formative early years, the child progressively appropriates into the domain of interior consciousness the configurations of meanings taken for granted by those closest to him/her. As such, he/she steadily begins to reproduce the values which have been imbibed. There is a sense of haphazardness here (the child would think and behave differently had he or she been raised by different significant others) as also inevitability. In this regard, it is worth quoting Berger and Luckmann at length:

Every individual is born into an objective social structure within which he encounters the significant others who are in charge of his socialization. These significant others are imposed upon him. Their definitions of his situation are posited for him as objective reality ... Since the child has no choice in the selection of his significant others, his identification with them is quasi-automatic. For the same reason, his internalization of their particular reality is quasi-inevitable. The child does not internalize the world of his significant others as one of many possible worlds. He internalizes it as the world, the only existent and only conceivable world, the world tout cort. It is for this reason that the world internalized in primary socialization is so much more firmly entrenched in consciousness than worlds internalized in secondary socializations. However much the original sense of inevitability may be weakened in subsequent disenchantments, the recollection of a never-to-be-repeated certainty - the certainty of the first dawn of reality - still adheres to the first world of childhood. (Berger and Luckmann 1966, pp. 151, 154-155)

It is for this reason that religious identities firmly transmitted to children by significant others during this formative period have a high probability of persisting throughout the individual's life. This assertion is substantiated by a wide range of studies in multiple international contexts, some longitudinal, which taken together reinforce the almost

\footnotetext{
${ }^{2}$ Berger and Luckmann's theoretical system relies here on the work of George Herbert Mead from whom they derive their concepts of primary and secondary socialisation as well as significant and generalised others. Other influences include Piaget, Cooley and Freud.
} 
axiomatic power of parental socialisation to embed worlds of meaning within the consciousness of the growing child (Birkelbach and Meulemann 2013; Hayes and Pittelkow 1993; Özdikmenli-Demir and Șahin-Kütük 2012; Stott 1988; van de Pol and van Tubergen 2014). For example, McGuckin et al. (2009) examined the influence of parents on the religiosity of children across ten countries. Of these, eight were described as 'at least nominally Christian samples' (Germany, Poland, Great Britain, Croatia, Finland, Netherlands, Sweden, Ireland), one Jewish (Israel) and one Muslim (Turkey). The authors differentiated the term 'religious socialisation' into three distinct categories depending on levels of parental involvement, i.e. 'no religious socialisation', 'incidental religious socialisation', and 'intentional religious socialisation'. Despite some national variation, they found consistently across all ten countries that 'Young people who were offered religious socialisation by their parents are not only more religious than the young people who did not receive religious socialisation, but they were more traditionally religious ... Parental influence did not promote indiscriminate religiosity, rather, it was likely to promote the religiosity of the parents.'

What are the mechanisms through which this operates in practice? Cornwall's (1988) study of twenty-seven Mormon congregations across the USA identified three ways in which the family directly influence the religious identity formation of the growing child. Firstly, parents supply a constellation of symbolic reference points for understanding the world and the role of human beings within it - transmitted, usually, through stories or 'grand narratives'. These provide the primary building blocks with which the child first engages in the process of meaning-making. Secondly, parents model religious behaviour through their own practice of a given religious tradition. The growing child thus observes, and progressively participates in, the rites and rituals considered proper for that religious reference group and comes to adopt, in the case of successful socialisation, an appropriate sense of existential comportment. Lastly, parental authority functions to channel the social interaction of the child into networks of association that corroborate the religious teaching administered within the home. Friendship choices and engagement with external spheres are thus constrained, for example, to contacts within the church community who share the same faith and indirectly consolidate the reference points of the symbolic universe posited by the family (cf. Berger's (1967, pp. 45-51) concept of 'plausibility structures'). Collaboratively, these mechanisms function to embed decisively within the consciousness of the growing child a set of meanings which intertwine deeply and intimately with their sense of self.

There is evidence to suggest that these processes pertain particularly to the formation of Muslim identity. Data generated from the 2003 Home Office Citizenship Survey found that rates of religious transmission are higher among Muslims than any other UK religious group. Analysis of data collected across three generations (parents' religious upbringing, parents' current level of religious practice, children's identification with a religion) demonstrates that rates of intergenerational religious attrition are highest among Christians, $38.3 \%$ of whom no longer identify with their ancestral religion by the third-generation. By contrast, $97.7 \%$ of third-generation Muslims continue to identify with Islam as do $88.9 \%$ of the third-generation belonging to other UK religions. ${ }^{3}$ A detailed exploration of

\footnotetext{
3 This should not obscure an increasing trend of 'de-conversion' among Western Muslims as documented by Cottee (2015).
} 
why this should be the case was undertaken by Scourfield et al. (2013) who conducted a qualitative study of 60 Muslim families with primary school age children (interviews conducted with 99 parents and 120 children) in Cardiff.

Scourfield et al. (2013) identified four key mechanisms through which religious identity is internalised by Muslim children raised in Britain. First, cognitive transmission - based on Harvey Whitehouse's doctrinal mode of religiosity - appertains particularly to the ritualistic nature of mainstream Sunni Islamic praxis (the five daily prayers or frequent recitations of prophetic litanies being two examples). Second, embodiment and habitus - rooted in the differing conceptions of Pierre Bourdieu and Saba Mahmood (who, unlike Bourdieu, hearkens back to an earlier conceptualisation of habitus as 'ethical cultivation' based on Aristotle) - refers to the way inward dispositions are nurtured through a range of micro-level socialisations including childhood religious ceremonies, parental choices relating to naming and dress or the display of material religion in the fabric of the home. Third, minority defence refers to the conflation of religious and minority ethnic identities vis-à-vis a majority culture that can sometimes be hostile or discriminatory. Lastly, religious organisations and congregations play a key role in providing a broader network of social confirmation for core ethno-religious values imbibed in the home. In particular, the hundreds of Islamic supplementary schools (makatib) operating out of mosques across the UK are instrumental here. In practice, these four mechanisms overlap and interplay in the child's lived experience to produce a deeply rooted religious (and ethnic cultural) identity:

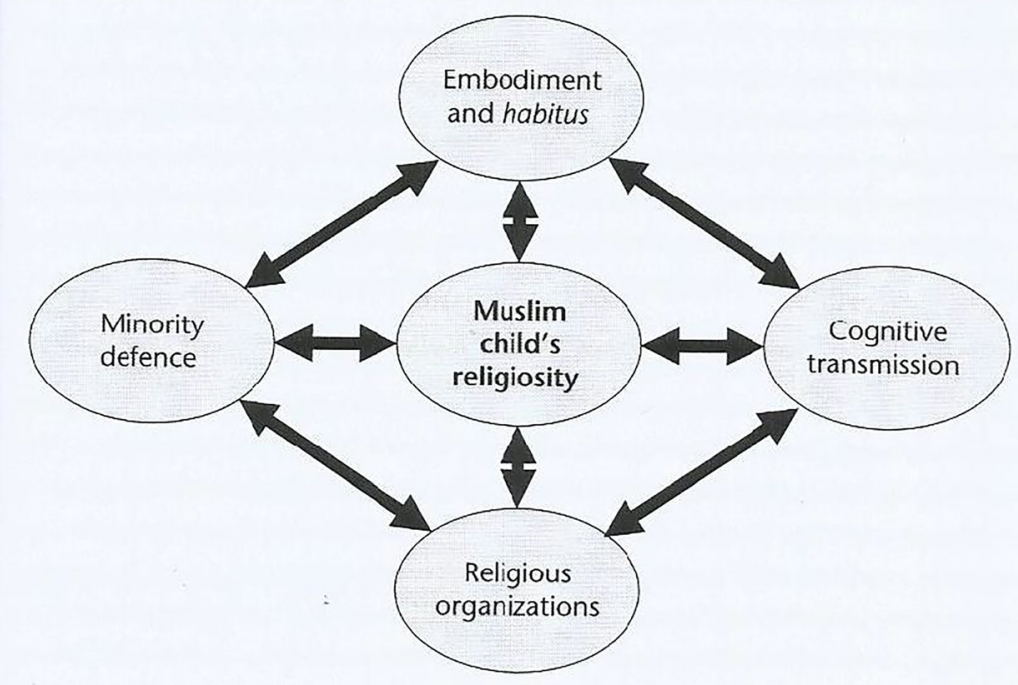

Figure 9.1. Influences on a Muslim child's religiosity.

(Scourfield et al. 2013, p. 205)

All of the above relates to the primary socialisation administered by caregivers in the home and bolstered through extended networks of social and family contacts that collectively reinforce the child's immediate Weltanschauung; as such, it substantiates in several important ways the salience of the 'direct transmission model' identified by 
Knott and Lee (2017) in their wide-ranging survey of academic literature on The Family and Ideological Transmission. Successful socialisation could be said to occur when the child perceives as essential to his/her own subjective identity those core values which constitute the meaning-system of the group in which he/she was raised: 'He now has not only an identity vis-à-vis this or that significant other, but an identity in general, which is subjectively apprehended as remaining the same no matter what others, significant or not, are encountered' (Berger and Luckmann 1966, p. 153). This latter point is important as it introduces the idea that primary socialisation is not conclusive and the individual, as he/she progresses through life, will become attached to new significant others and encounter a range of alternate meaning-systems that may well contradict or undermine the substantive content internalised in that admittedly powerful and nostalgic 'first dawn of reality'.

\section{Secondary socialisation and the contemporary British collective conscience}

In relatively simple, pre-modern societies (the tribe or village-akin to Durkheim's concept of 'mechanical solidarity'), it can be surmised that a basic correspondence existed between the core content of the values internalised during primary socialisation and those of the necessarily limited wider society. The more complex, differentiated scenario of advanced or post-industrial societies (more akin to Durkheim's notion of 'organic solidarity') is different. From the outset, globalisation reaches into individual homes and collaborates with parents to inject into local meaning-systems the values of a 'McWorld culture' disseminated through the mass media of television and the Internet (Barber 2011 [1995]). The child, as he/she progresses through adolescence, is increasingly exposed to new social worlds outside of the home. Peer groups congregate around shared constellations of meaning which may well fly in the face of parental expectations ('Don't worry mum, we're revising!' texts Jenny as her friend shoots heroin into her arm). The Durkheimian division of labour integral to modern societies sets up multiple arenas of activity each of which requires specialised knowledge and training (Durkheim 1984 [1933]). Getting a new job thus demands successful socialisation into a new world with its attendant uniform, protocol and lingo. Over the course of a lifetime, an individual may thus be re-socialised numerous times, yet each of these experiences of secondary socialisation build upon, rather than displace or obviate, the foundational experience of primary socialisation: 'The 'sub-worlds'

\footnotetext{
${ }^{4}$ It is worth pointing out here, in passing, that the vehement 'New Atheism' of recent years considers any form of pre-pubescent religious instruction to be child abuse. For instance, 'How could any decent person think it right to label four-year-old children with the cosmic and theological opinions of their parents? ... Our society, including the non-religious sector, has accepted the preposterous idea that it is normal and right to indoctrinate tiny children in the religion of their parents...' (Dawkins 2006, pp. 380-381). Or 'The obsession with children, and with rigid control over their upbringing, has been part of every system of absolute authority ... If religious instruction were not allowed until the child had attained the age of reason, we would be living in a quite different world' (Hitchens 2007, p. 376). These excerpts seem to overlook the basic fact that socialisation cannot take place in a vacuum but is necessarily freighted with the cultural and cognitive assumptions of the significant others. After all, would Dawkins and Hitchens themselves carefully resist the temptation of extolling the virtues of atheism or indulging in their usually caustic denigrations of religion within earshot of their own young and impressionable children?
} 
internalized in secondary socialization are generally partial realities in contrast to the 'base-world' acquired in primary socialization' (Berger and Luckmann 1966, p. 158). Put differently, a range of software packages can be downloaded onto the hardware machinery of a single computer.

While the sub-worlds of office, college and heroin den may differ qualitatively in nature, each operates within the parameters of a 'symbolic universe' defined as '...bodies of theoretical tradition that integrate different provinces of meaning and encompass the institutional order in a symbolic totality...' (Berger and Luckmann 1966, p. 113)—which supplies the materials for a broad social consensus in relation to their activities. In its most basic function as a nomic legitimation of diverse human activity, the symbolic universe supplies the reservoir of meanings by which a promotion is celebrated, a flunked exam rued and an addict decried as a reckless reprobate. Emile Durkheim's concept of the 'collective conscience' is relevant here. ${ }^{5}$ Defined as '.... a body of beliefs, practices and collective sentiments which are ... diffused throughout the society, define social purposes, give meaning to action and generally structure the pattern of social life' (Morrison 1995, p. 131), Durkheim characterises the collective conscience as a homogenising force which provides the basic animus of a society through four interrelated elements. First, the volume of the collective conscience refers to its pervasiveness and its ability to envelop individual members. Second, its intensity refers to its ability to penetrate individual consciousness shaping thought and behaviour. Third, its determinateness refers to its firmness and durability measured by its ability to absorb transgressions or incipient rumblings of change. Lastly, its content can be either religious or secular, the former deriving its authority from ecclesiastical authorities or scripture and the latter from political, economic or scientific social apparatus sanctioned through a restitutive system of law (see Morrison 1995, 131-133). In societies of mechanical solidarity, the collective conscience was strong, pervasive and religious in character functioning as the 'social glue' that bound people together. In more modern societies of organic solidarity, however, 'The collective conscience becomes a diffuse, abstract 'cult of the individual' that, as a civil religion, supplies ultimate principles and justifications but cannot bear the whole weight of social cohesion' (Scott 2014, p. 95). The reference to civil religion is apposite:

...in advanced industrial societies, which are increasingly secular in terms of institutional religions, civic [sic] religions (such as the celebration of the state or civil society) now serve the same functions of prescribing the overall values of society, providing social cohesion, and facilitating emotional expression. In other words, civil religions offer a 'functional equivalent' or 'functional alternative' to institutional religions, since they meet the same needs within the social system. (Scott 2014, p. 78)

The social conditions of contemporary Britain reflect a differentiated, 'weak' collective conscience which, in practice, exhibits features of civil religion

\footnotetext{
$\overline{5}$ The same concept is sometimes referred to as the 'conscience collective' or 'collective consciousness'.
} 
particularly when juxtaposed to the decline of traditionally strong religious and national identities. As such, 'functional alternatives' such as football or the monarchy thrive (Moreton 2010). The cumulative impact of industrialisation and secularisation in weakening the historically Christian fabric of the nation have been well-documented and, while Anglicanism remains England's official state religion, core processes of 'structural and functional differentiation' have situated religion principally within the private sphere (Bruce 2002; Casanova 1994, pp. 40-66). According to Callum Brown, the 1960s was the definitive decade in which religious observance saw a precipitous decline in Britain. As he dramatically puts it:

For over a thousand years, Christianity penetrated deeply into the lives of the [British] people, enduring Reformation, Enlightenment and the industrial revolution ... Then, really quite suddenly in 1963, something very profound ruptured the character of the nation and its people, sending organised Christianity on a downward spiral to the margins of social significance. In unprecedented numbers, the British people since the 1960s have stopped going to church, have allowed their church membership to lapse, have stopped marrying in church and have neglected to baptise their children ... Since then, a formerly religious people have entirely forsaken organised Christianity in a sudden plunge into a truly secular condition. (Brown 2001, p. 1)

A Church of England report on the faith of under $30 \mathrm{~s}$ in Britain, termed 'Generation Y', similarly found that 'only one in two believes in God (lower than the national average), that levels of religious observance are very low, and that the overwhelming feeling is one of disinterest and disengagement' (Spencer 2010). While Grace Davie's studies of religion in Britain and Europe have popularised the terms 'believing without belonging' and 'vicarious religion' to mitigate prior unilinear conceptions of the secularisation process (Davie 2000, 1994), the second edition of her acclaimed Religion in Britain continues to demonstrate a steady decline in statistical indices of religious observance (Davie 2015, pp. 41-67). It came as little surprise then when, sometime around 2015, Britons self-identifying as 'no religion' outnumbered Christians to become a new cultural majority (Woodhead 2016).

Anderson (1983), in his classic work Imagined Communities, suggests that nationalism-or strong patriotic fervour-is a peculiarly modern phenomenon that emerges partly in response to the decline of traditionally religious systems of belief. It therefore functions to supply symbols of unity and solidarity (such as the flag) as a type of surrogate religion. While this may have been true for Britain during much of the twentieth century, especially during the emotionally tense periods of the two World Wars, narratives of national identity, like religion, have more recently been in decline with the strong pride of an imperial past giving way to more nebulous and fragmented notions of Britishness (Fox 2004). An IpsosMORI (2007), p. 4) survey on British identity conducted with 16-21-year olds found 'a fundamental lack of emotional 
resonance amongst young people with the concept of Britishness ... For many young people Britain represents an old, hierarchical, traditional, political discourse that does not fit with the fresh, inventive, messy and often chaotic world of a teenager.' Globalisation, immigration and the increasing 'technologisation' of culture all play key roles here:

In a country that is now a container of African and Asian cultures, the sense of what it is to be British can never again have the same confidence and surety ... Is it at all possible, in global times, to regain a coherent and integral sense of identity? Continuity and historicity of identity are challenged by the immediacy and intensity of global cultural confrontations. The comforts of Tradition are fundamentally challenged by the imperative to forge a new self-interpretation... (Robins 1991, p. 40)

This 'imperative to forge a new self-interpretation' indicates a key shift towards individualisation in modern societies, in which a 'wider cultural 'turn to the self' combines with a consumerist 'culture of choice' (Woodhead and Heelas 2000 , p. 345) to produce, in José Casanova's (1994, p. 53) terms, 'the cult of the individual [which] has indeed become, as foreseen by Durkheim, the religion of modernity.'

\section{Migration and the formation of British Muslim identity between primary and secondary socialisations}

This attempt to adumbrate some contours of the British collective conscience is important as it represents the broader social milieu into which Scourfield et al.'s (2013) Muslim child, having experienced a stronger-than-average programme of cultural and religious nurture, will progressively emerge. In essence, all of the individual's experiences of both primary and secondary socialisation unavoidably take place within this broader social milieu which to a lesser or greater extent influences them-particularly if, as a third-generation Muslim child, their parents were also born and raised in Britain. First-generation migrants, however, approach British society from a very different standpoint to their diaspora-born offspring, and it is to their experiences that we now turn.

A stark fact of British Islam is germane here: the overwhelming extent to which it is ensconced within antecedent and ongoing processes of immigration. While early post-war migration in the 1950s, 1960s and 1970s was primarily economically motivated and from former British colonies in South Asia, later migration has been more diverse encompassing asylum seekers from countries such as Afghanistan, Iraq and Somalia or wealthy investors and skilled professionals from North Africa and the Middle East (Lewis 2007, pp. 19-21; GilliatRay 2010, pp. 44-53). This diversity in motivation and geography does not occlude the core sociological fact that the primary socialisation of firstgeneration migrants took place in a very different socio-cultural milieu from the country to which they relocated. Consequently, upon arrival, they were obliged to navigate a new set of cultural mores relating, inter alia, to the 
language, food, dress and religion of the newly adopted country. Given that the substantive contents of both primary and a range of secondary socialisations had already congealed in subjective consciousness prior to encountering the new reality, a sense of emotional distance could well be expected from the new culture whose collective conscience might appear alien and incomprehensiblemore so if exacerbated by incidents of racism or discrimination. This would especially have been true for early South Asian migrants many of whom formed, to use Tariq Modood's memorable phrase, 'a semi-industrialised, newly urbanised working class community only one generation away from rural peasantry' (cited in Mandaville 2001, p. 123). In such a scenario, it is entirely understandable why early arrivals, enduring together the uprooting dislocation of migration and bound by shared cultural memories, sought comradeship in each other and set about re-creating in the new context norms of life familiar from the country of origin (Brown 2006).

Studies of Muslim settlement in Britain concur that the earliest post-war arrivals were largely unskilled male workers who laboured under the presumption of a 'myth of return' (Gilliat-Ray 2010; Ansari 2004; Anwar 1979). Changes in immigration legislation in the 1960s and 1970s expedited the arrival of women; the rudiments of community formation were thus initiated accompanied by a conceptual shift, in the mind of the migrant, from sojourner to settler (Lewis 2007, pp. 16-18). From the perspective of the sociology of knowledge, this presented a very specific challenge, i.e. to generate in space and time and maintain as plausible to subjective consciousness a sub-universe of meaning lacking any social support. Berger's (1967, pp. 45-51) concept of 'plausibility structures' is relevant here which, in his collaboration with Luckmann, is expressed as follows: 'All socially meaningful definitions of reality must be objectivated by social processes. Consequently, sub-universes require subsocieties as their objectivating base, and counter-definitions of reality require counter-societies' (Berger and Luckmann 1966, p. 145). Put differently, any religious group newly arrived in Britain - whether Neocatechumenate, Hare Krishna or Soka Gakkai-should they wish to maintain fidelity to their preimmigration definitions of reality, must instantiate in space and time and enshrine in institutional constructs (as part of the first two processes of the tripartite system outlined earlier, namely externalisation and objectivation) core elements of their symbolic universe to prevent 'cognitive liquidation' into the dominant structures of meaning which pervade the wider collective conscience. With reference to the Tablighi Jama'at, construction of a large headquarters in Dewsbury was completed in 1982 manned by dedicated personnel, and augmented by regular teams of visiting TJ delegations, allowing the movement's realitydefining potential to steadily actualise. More generally, processes of mosquebuilding, accompanied gradually by wider institutional infrastructures, gained momentum from the 1970 s, enabling an emergent British Islam to be undergirded by a legitimating social apparatus.

Yet the religious identity of early migrants, as it took root and developed in the new context, fused in important ways with an ethnic cultural one derived from the countries of origin (Geaves 1996; Werbner 2002; Sardar 2008). It is useful to distinguish here between three key pivots around which British 
Muslim identity could be said to revolve, i.e. ethnicity, nationality and religion. While several scholars intimate this conceptual distinction (Mustafa 2015; Ansari 2004; Bagguley and Hussain 2005), Ron Geaves, when considering the legacy of the Victorian Muslim convert Abdullah Quilliam for young Muslims today, reproduces from his earlier career the following diagram:

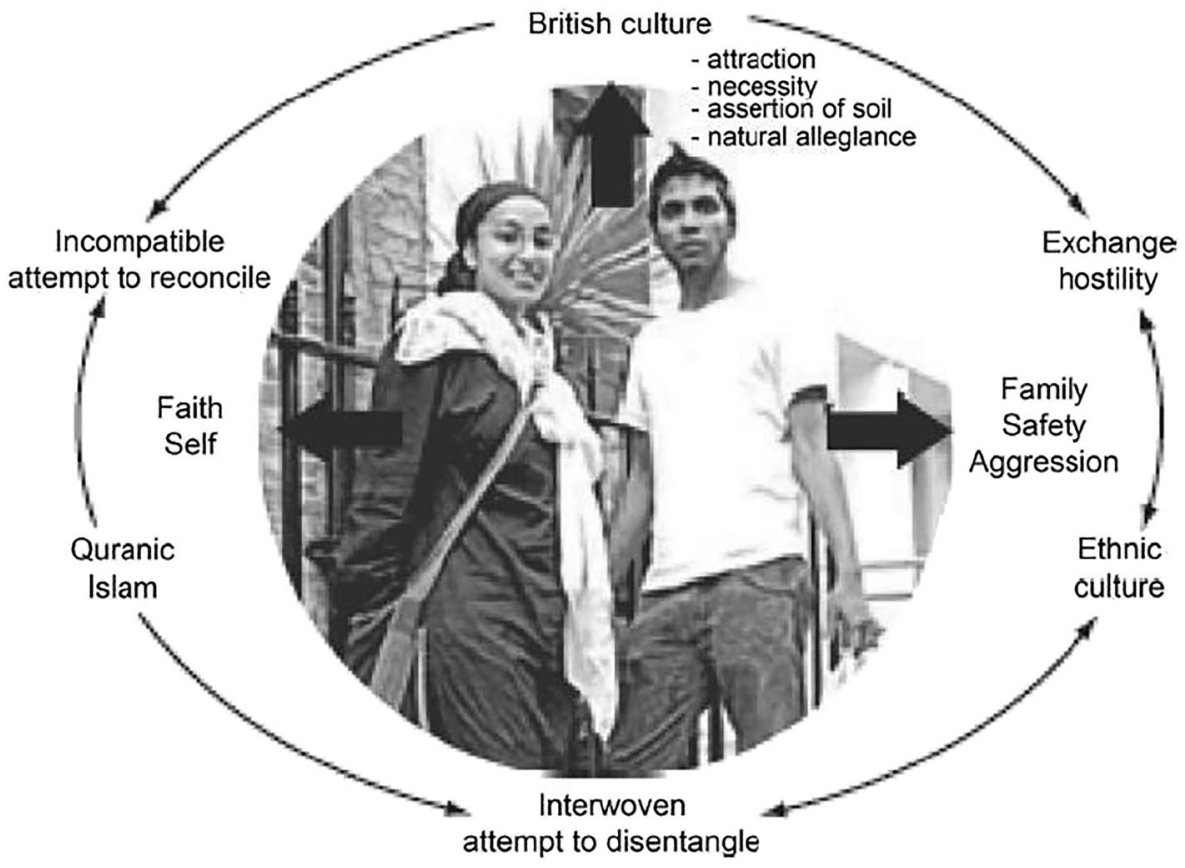

Ethnicity, nationality and religion in the construction of British Muslim identity (Geaves 2010, p. 301).

Scions of the dominant culture who convert to Islam, such as Abdullah Quilliam, may well find that elements of their ethnicity and nationality enmesh intimately and unproblematically (Zebiri 2007; Jawad 2012). Put differently, the transformation of meaning-system implicit to conversion does not affect the pigmentation of one's skin - nor, as Abd-allah (2004) points out, does it necessitate cultural apostasy (though it may well moderate one's patriotic fervour (Gilham 2014), preclude participation in such ubiquitous aspects of the national culture as regular pub attendance (see Fox 2004, p. 88) or be accompanied by a level of enculturation into certain mores of Muslim-majority societies (Butt 2020)). In cases of deep and profound conversion however, termed 'alternation' by Berger and Luckmann (1966, p. 176), the content of the meaning-system implanted in subjective consciousness during the powerful experience of childhood primary socialisation must be substantially altered or displaced. This may cause a rupture in terms of the individual's self-conceptualisation of identity and the efficacy of such a conversion often depends, in practice, upon the cultivation of strong personal bonds forged with new significant others who mediate the 'plausibility structure' of the receiving group: 'No radical transformation of 
subjective reality (including, of course, identity) is possible without such identification, which inevitably replicates childhood experiences of emotional dependency on significant others. These significant others are the guides into the new reality' (Berger and Luckmann 1966, p. 177). The deeply reverential, paternal relationship between the prominent American Muslim convert Shaykh Hamza Yusuf and his Mauritanian teacher Shaykh Murabit al-Hajj provides a good example of this (see al-Hajj and Yusuf 2001, pp. 1-5).

While an easy alliance between ethnicity and nationality also pertains in various Muslim-majority contexts, it is thrown into disarray by the act of migration and the concomitant transitioning of the individual into a minority community surrounded by an alien host culture. Though legally naturalised citizens and co-religionists of the numerically fewer converts to Islam, Muslim migrants from overseas have a very different relationship with the British collective conscience. For them, it is the conjunction of ethnicity and religion, indelibly wrought in consciousness through processes of primary and secondary socialisation administered abroad, that constitutes the principal matrix through which British culture is apprehended and engaged.

Food, as an important marker of cultural identity, illustrates this point nicely. While conducting fieldwork with both first-generation and British-born Tablighis, I quickly realised that socialisation has a physiological dimension brought into sharp relief by migration. Put differently, first-generation migrants quite literally taste food differently to their British-born offspring - or indeed the wider population (Timol 2019). This became evident simply through observing the tea-drinking habits of my respondents while on khuruj. Unlike their British-born counterparts who were generally comfortable with either, I found elderly migrants almost exclusively preferred 'desi chai' - equal amounts of milk and water boiled on a stove with a teabag and sometimes flavoured with spices - and usually looked askance at 'English tea' (hot water from a kettle poured onto a teabag usually with a splash of milk). Indeed, on one occasion, I heard an elderly British Pakistani scornfully dismiss English tea as no more than 'weak, flavoured water'. Such proclivities of the palate, as Geaves (1996) argues more generally, were cultivated through processes of socialisation administered abroad in which religion is usually internalised into subjective consciousness as an intrinsic component of a broader ethnic culture. To illustrate this differently, biryani and Jumu'ah namaz (the Friday prayer) might well appear to many first-generation migrants as inseparable components of a single ethno-religious package uncritically imbibed in the ancestral village while, in comparison, bangers and mash or the Eucharist appear as exotic yet essentially irrelevant alternatives.

There is some evidence that the exigencies of immigration can reinvigorate religious consciousness as the dislocation of the experience allows the continuity of a religious identity to function as an anchor in the new society (Duderija 2008, pp. 372-373). This certainly seems to have been a major attraction of the Tablighi Jama'at for early migrants, as the movement's regular retreats allowed the reproduction of key South Asian cultural mores within the safe space of the mosque to generate a veritable 'home away from home' in Britain (Sikand 1998). Meaning-systems and selfconceptualisations of identity, however, are malleable and as fresh processes of secondary socialisation become activated in diaspora, some migrants may well learn to navigate the new culture with remarkable degrees of success. The 'rags to riches' story 
of Sir Anwar Parvez (Lewis 2007, pp. 16-17), or the important leadership role played by Shaykh Dr. Zaki Badawi for British Muslims in the 1980s and 1990s (Gilliat-Ray 2010, pp. 57-58), provide good examples of this. Others though-such as Ebrahim Bawa Rangooni as cited in Sikand (1998) - may cultivate oppositional identities and, even after several decades in the country, continue to look askance at the strange customs of the ungodly people they live among. ${ }^{6}$

The situation, of course, is different for their offspring. Their primary socialisation, as explicated in detail above, takes place in Britain and their secondary socialisations induce them, with varying degrees of assimilation, into the British collective conscience (which in turn, with varying degrees of success, is internalised by them). Yet, the fact that their socialising personnel, the biographically significant others with whom they were domiciled in the formative early years, were themselves products of another culture substantially impacts their crucial primary socialisation experience. Consequently, as Penn and Lambert (2009) show, the immigrant's child has a foot in multiple worlds.

\section{Language as a window into religion, ethnicity and national culture}

Children of immigrants raised in diaspora draw upon multiple sources of cultural capital when engaging, usually subconsciously, in the complex and messy process of identity construction (Alba 2005; Penn and Lambert 2009; Hirsch 2018). It is useful to draw here on Geaves' tripartite conceptualisation of ethnicity, religion and nationality again. While Geaves seems to give equal weighting to each of these constitutive components, triangulating his model with Berger and Luckmann's concepts of primary and secondary socialisation helps to better gauge how identity is refracted across generations. My argument here is that key elements of an ethno-religious identity are internalised by British-born Muslims during their childhood primary socialisationindeed, as was asserted earlier, ethnic and religious identities often appear inseparable in the consciousness of first-generation migrants who constitute the 'socialising personnel' or 'significant others' of the British-born generation. By contrast, Geaves' third component of nationality is appropriated most significantly during secondary socialisations into heterogeneous spheres of the wider collective conscience.

This point may be illustrated through the prism of language. Ethnicity is manifested in local dialects imported from countries of origin - Sylheti, Pashtu, Gujarati, Somali or Kurdish for example - often internalised in childhood primary socialisation as 'mother tongues'. The national language, by contrast, refers to the dominant societal lingua franca - English in Britain - learnt in secondary socialisation, if not primary. Finally, the chief language of what Geaves terms 'Quranic Islam' is, of course, Arabic, though this is usually mediated for South Asian Muslims through the auxiliary religious lingua franca of Urdu — rote Arabic being taught in the maktab solely for liturgical purposes.

\footnotetext{
${ }^{6}$ Fiction provides a rich repertoire of alternative trajectories. The desire to efface any incongruous or embarrassing elements of one's ethnic persona may lead to one acting 'more royal than the king' as typified by Saladin Chamcha, the incorrigible Anglophile of Salman Rushdie's novel The Satanic Verses. Alternatively, the cognitive dissonance generated when disparate systems of meaning simultaneously impinge upon subjective consciousness can give rise to intense anxiety as exemplified in the biographical tale of Changez, the Pakistani American soliloquist of Mohsin Hamid's brilliantly ambivalent The Reluctant Fundamentalist.
} 
That most second-generation British-born Muslims are multilingual to some degree in all these languages is usually taken to be axiomatic (Lewis 2007, p. 43), but what I wish to argue here is that shifts in the particular weighting attributed to each language signals a clear transition from first-generation to diaspora-born identities.

For example, a typical South Asian elderly migrant might speak Sylheti or Gujarati in the home, Urdu at the mosque and a broken, and highly accented, English at the supermarket checkout. By contrast, his British-born counterpart principally articulates in fluent English in all three locations - the most significant exceptions perhaps being when conversing with his (grand) parents in an (halting) ethnic tongue or other firstgeneration elders at the mosque in either the ethnic tongue or (halting) Urdu. My extensive interaction with members of the British Tablighi Jama'at over 18 months of fieldwork unequivocally found that for a younger generation of activists, English has substantially superseded the ethnic tongues internalised in childhood. This reflects a more general shift among second-generation Muslims as wonderfully illustrated during a weekend mosque retreat (khuruj) I joined in October 2013. The leader of the group (amir) was a white-bearded elder - albeit one who spoke good English - while the bulk of the participants consisted of British-born teenagers, mainly of Gujarati background, who occasionally participated in Tablighi outings. During the morning study circle, we broke out into a handful of smaller groups for around $20 \mathrm{~min}$ to practice correct pronunciation of Qur'anic Arabic (tajweed). After we regrouped, the amir explained: 'We should take out special time to learn tajweed because we often make mistakes without realising. That's because Arabic is not our mother tongue. Our mother tongue is...' Here, he paused expectantly; in my fieldnotes, I recorded the following: 'Immediately the youngsters said in chorus 'English!' at exactly the same moment he said 'Gujarati' - a beautiful symbol of the generational gap.' This shift from ethnic tongues to the national language is an unsurprising feature of the general stock of academic knowledge on immigrant communities and their offspring. Alba, for instance, in his study of North Africans in France, Turks in Germany and Mexicans in the USA found that

Proficiency in the mainstream language is close to universal in the second generation of all three groups, which is educated typically in the public schools of the receiving society. Some loss of the mother tongue is also common, especially since members of the second generation frequently prefer to speak the mainstream language ... In the U.S. but also in France, the second generation pattern of 'responding to their parents in the dominant language while understanding what the parents say in the mother tongue' is well known... (Alba 2005, p. 36)

This transition in language usage has been accompanied by a transition in attitudes. Elderly Tablighis - as with 'English tea' - might well express a certain disdain for the English language - either, perhaps, to disguise a lack of proficiency, because of an emotional attachment to the mother tongue or, as Sikand (1998) suggests, because they see it as an inextricable symbol of the wider secular society they wish to save themselves from. British-born Tablighis, by contrast, speak English as a taken-forgranted component of their normative social reality. In this regard, Geaves (2010, p. 
301) notes that '...the second generation find themselves being drawn towards British identity as a natural allegiance of birth and as a result of socialisation processes.' Deploying Berger and Luckmann, as this article has done, allows us to nuance these 'socialisation processes' by distinguishing between primary and secondary socialisations. Given the ubiquitousness of digital media in today's world, an additional point can be made: English - and an attendant constellation of cultural values - can now be regularly accessed by toddlers on screens in the home via YouTube, Netflix or the like, even if neither parent is fluent in the language. In fact, so pronounced has the impact of the digital revolution become on the lived experience of modern youth that it may plausibly constitute a disembodied site of 'tertiary socialisation' that cuts across the traditional modalities of primary and secondary socialisation proposed by Berger and Luckmann over 50 years ago.?

\section{Coming home: 'intra-religious conversion' in contemporary Islam ${ }^{8}$}

While such shifting dynamics of language usage apply to immigrant communities in general, intergenerational transmission of religion, as has already been pointed out, occurs more successfully among Muslims than other UK faith communities. A further finding of the literature on Muslims in the West relates to the decoupling of religion from ethnicity among the second generation (Jacobson 1997; Duderija 2008; DeHanas 2016). Mandaville expresses this clearly:

The younger generation of diasporic South Asian Muslims ... often questions the Islam of its parents, regarding the latter as tainted with the 'local culture' of the subcontinent and therefore not 'true' Islam. This has in many cases prompted a return by the younger generation to another point of origin, Muhammad's Medina, which it regards as a source of 'pure' Islam. (Mandaville 2001, p. 90)

The reasons for this are varied and may include the 'double marginality' of the diaspora-born Muslim who finds himself unable to relate fully to either the ethnic culture of his parents or the secular assumptions of the mainstream, the intensity of public Islamophobia which, turtle-like, causes the diaspora-born Muslim to recede into the defensive shell of religion, or the impact of various international crises involving Muslim people that cause an 'ummatic' allegiance to be privileged over an ethnic or national one (Geaves 1996; Parekh 2008; Voas and Fleischmann 2012). Revivalist movements developed overseas and transplanted into the UK can play an important role in reinvigorating a specifically religious identity for second-generation Muslims

\footnotetext{
${ }^{7}$ As Amir Saeed (2017, pp. 137-138) puts it: 'For young people today, there is nothing 'new' about digital media; for them, digital media has always existed. Whether accessing the Internet through a desktop computer or connecting through short message services (SMS) via mobile phones, digital/electronic media are omnipresent in Western contemporary society. New media specialist and pioneer Howard Rheingold has argued that 'search engines have replaced libraries' for young people in the digital age...'

${ }^{8}$ By 'intra-religious conversion' is meant a shift from a nominal or lax religious identity to one in which religion becomes central to the individual's sense of self. This became a consistent motif of my interviews with British Tablighis and, arguably, is the raison d'être of the movement.
} 
(Hamid 2015). Inge's (2017) study of Salafi women in London, for example, found that a commitment to the movement's ideals occasioned lifestyle changes significant enough to be warranted conversion. Similarly, my study of British-born Tablighi men found that participation in the movement led to an intensification of religiosity that often surpassed - and sometimes bewildered - that of their parents. An example of this is Hafiz Raees, a 34-year-old science teacher from Blackburn who memorised the Qur'an as a child at the behest of his parents. ${ }^{9}$ Yet, this was done rather mechanically, he felt, and thus largely bereft of spirituality. It was only when he began to participate in TJ voluntarily in his late teens that an 'awakening' of sorts was experienced:

So all these years I'd learnt the Qur'an but I didn't know the significance ... [or have] any understanding that this is probably the biggest achievement of my life. So that jama'at [TJ outing], sort of, brought this to town, it hit me, hit me quite hard. That this religion is not just something that you go through the motions but it's something which you have to fully enter into and something which will ... change you in every way. So these 40 days were a real eye-opener, you know, and like the proverb goes the eye of the heart was opened.

What is significant here is that Raees memorised the Qur'an as an extension of his primary socialisation experiences, but subsequently drifted from the practice of his faith - as many other respondents also reported. Yahya for example, today a devoted Tablighi with a large beard and turban, described his upbringing to me as predominantly cultural rather than religious:

Most of my friends [at college] were Asian Muslims. So it was a strong Asian identity, not very religious, very secular ... we were all very secular, but we were Asians and we were Indians and we were Muslims ... but we didn't pray regularly [laughs], and we weren't really practising.

Conversion to TJ can then be conceptualised as a twin process of desocialisation and resocialisation that proceeds concurrently in neophyte consciousness. Desocialisation takes place from the taken-for-granted assumptions of the local subculture nestled within the wider collective conscience-whose values, as was asserted earlier, are rooted far less deeply in subjective consciousness and hence more easily displaceable - while resocialisation occurs into the rituals, mores and meaningsystem of the group. The praxis through which this is achieved is khuruj, or consistent mosque-based retreats, which extricate the neophyte from the day-to-day enmeshments of ordinary life and thrust him, both physically and conceptually, into an alternative world. The messages he hears here - and often the cultural idioms through which they are delivered - can resonate in emotionally charged ways with the content of the meaning-system first internalised as taken-for-granted reality during the powerful experience of childhood primary socialisation. Unlike the journey of the convert to Islam then, who was raised in a different religious and usually ethnic cultural milieu,

\footnotetext{
${ }^{9}$ Raees is a pseudonym; all respondents have been anonymised in this paper.
} 
the inarticulate sense of being a Muslim implanted in consciousness during childhood can function for the diaspora-born Muslim as the crucial substratum of a later 'intrareligious conversion' subjectively experienced as a return to one's biographical roots. As Umar expressed this:

So then eventually ... that seed started to grow again and ... I came out [on khuruj] one day, I decided. Well I didn't decide, Allah takes you out depending on your talab and your desire. So anyway I managed to come out and when I started coming out one day, once a month it went well. Obviously, I didn't go for such a long period ... but it was like basically coming back home, if you know what I mean? You know, it's like living away from where you live. You went into another country and you come back and you'll always have like a connection to that place, do you know what I mean?

An interesting observation about my interview sample is that only six of the total $(6 / 59)$ were third-generation British-born Muslims, all of whom were young sympathisers experimenting with the movement. In contrast, all the dedicated British-born Tablighis I interviewed who were not converts to Islam (17/21) were second-generation children of immigrants. This finding - as Voas and Fleischmann (2012, p. 538) also note about Western-born Muslims more generally - flatly refutes Herberg's (1955) classic thesis of 'third generation return' based on his application of 'Hansen's Law' to the situation of immigrant religion in mid-century America: 'What the son wishes to forget the grandson wishes to remember.' Not only does this indicate the extent to which grassroots intergenerational transmission has successfully occurred in British TJ but, more significantly, that the experiences of the next generation of Muslim youth are now frequently mediated with reference to a British-born generation's configurations of cultural norms. As Mandaville (2001, p. 124) puts this, 'What is crucial here is the rendering of Islam in an idiom comprehensible to those Muslims who have grown up in Western society and who possess certain Western norms in addition to Islam.'

My interview with Hanzalah nicely illustrated this cultural evolution of TJ over generations. A highly devoted Tablighi who has undertaken ten separate four-month khuruj outings to various international locations (our interview took place just after his return from Argentina), he was also among the first of the diaspora-born generation to acquire postgraduate education and has balanced his TJ activism with a successful career as a senior accountant. His first experience with the Tablighi Jama'at on a weekend khuruj in the late $1980 \mathrm{~s}$, however, was largely negative. As he described it to me, 'They were the first-generation as such, therefore the understanding of the challenges and issues that we see now - sex, drugs ... rock and roll that sort of thing weren't prevalent then ... at the time I thought of it like oh, I don't need this ... it didn't really appeal to me.' After a several year hiatus, Hanzalah participated in another weekend khuruj in the early 1990s. This coincided with a wider influx of British-born activists resulting in a very different experience:

One of the main things was the fact ... you had British-born, English-speaking guys leading the effort. So, you know, all the conversations were in English. The ta'lim [study circle] was in English. The programmes were in English, so 
immediately, you know, you feel much more comfortable. The food was more in line with what we were used to. Aksy was there so, you know, he was making all sorts of stuff like, breakfast was wow, you know, never had a breakfast like this at home, never mind! So I think it was the whole set-up, it was like someone had just dragged it from a prehistoric era into the modern world.

\section{Diaspora religiosity as a cultural mélange}

In foregrounding their new-found religiosity though, the diaspora-born generation cannotnor, it seems, do they particularly want to - simply disavow their ethnic heritage. This was aptly illustrated to me when, as part of my fieldwork, I participated in a continuous TJ khuruj to Bulgaria for 42 days (Timol 2015). The group (jama'at) I joined was young (aged between 27 and 35), entirely British-born and mainly of South Asian ethnic ancestry. Our amir decided that, as a declaration of our good intentions, we would feed the entire congregation in every mosque visited. This usually attracted $40-50$ people and, interestingly, the group's ethnic heritage was implicated in the food offered as hospitality. The amirdespite being of mixed race ethnicity himself (white Irish-Spanish and Gujarati)—would proudly announce to the locals that the jama'at was going to cook Hindi ta'am (Indian food) which usually transpired to be the famed Gujarati dish daar chaawal (spicy lentil curry served on rice). Similarly, when purchasing supplies in Dewsbury prior to departure, the jama'at procured several bags of the Indian savoury snack 'Bombay Mix'. Yet, when serving this, we quickly learnt it was far too spicy for the Bulgarian palate and - until the amir explicitly instructed against offering it to locals telling the jama'at to instead eat it themselves - several group members watched with great mirth the animated reactions of surprised locals who had unwittingly tried some.

Such culinary choices indicate a sense of unconscious affiliation, even pride, with aspects of the South Asian cultural ancestry group members shared. This was perhaps accentuated by the fact the jama'at was thrust into an entirely new socio-cultural setting which caused elements of their own identity to be foregrounded. Further, the fact that all Tablighi novitiates are required to undertake a continuous four-month khuruj to South Asia, where the movement's international headquarters are based, serves to reconnect diaspora-born youth with their ethnic cultural heritage; indeed, many return having become fluent in Urdu. More generally though, I would argue that the cultural idioms of a particular ethnic heritage - which not infrequently function as the carriers of religion-are indelibly stamped on an individual identity through the powerful formative experience of primary socialisation. Hence, they ineluctably interweave with the individual's sense of self in ways that cannot easily be disregarded. Despite the idealised vision of a de-territorialised, a-cultural Islam commonly associated with the movement (Roy 2004), Inge's fieldwork among British Salafis similarly found this to be the case. Amina, for instance, a Salafi woman of Eritrean ethnicity, reflected:

I can't see [myself] marrying any other cultural background guy. I don't know, I just, within myself, I love my culture as much as I love my din [religion] - of 
course, my din comes before my culture, but to me, I just - I wanna sit there with my mother-in-law and, you know, do the traditional stuff. (Inge 2017, p. 201)

Dress, along with food and language, is another important marker of cultural identity. South Asian ethnic dress codes differ depending on country of origin: the shalwar kameez is emblematic of traditional Pakistani dress, kafni patloon or the kurta typical of Indians and the lungi common among Bangladeshis. Each of these was imported into Britain by firstgeneration migrants but, just as ethnic tongues have largely been supplanted by English (and a growing tendency to learn Arabic, I noted) among British-born Tablighis, changing dress codes similarly indicate a shift, in terms of Geaves' tripartite model of Muslim identity, from ethnicity to both nationality and religion.

A defining feature of the Tablighi Jama'at lies in its insistence on maintaining a distinct Muslim identity through dress. Consequently, followers are often recognisable by their flowing robes, turbans or hats which, along with growing the beard, become outward symbols of an intra-religious conversion experience - an ensemble which jars conspicuously with the taken-for-granted norms of the British collective conscience. Yet, many Tablighis I interviewed are simultaneously secular-educated professionals inhabiting disparate fields in society as accountants, architects, teachers, civil servants or solicitors. Consequently, they would think nothing of wearing a suit and tie to work and then changing into a robe and turban when attending the mosque in the evening. As Hanzalah put this:

I've represented my firm in meetings all over the world. I go in a suit because I'm traveling on company business, so I don't have an issue. The company's very relaxed. I'm not too keen on wearing ties so they don't have an issue with that whatsoever. But obviously, I can't take my beard off and put it away for four or five days while I go on business.

When attending the mosque or participating in khuruj however, I noted that rather than the specifically ethnic dress of their parents, British-born Tablighis could be seen eclectically selecting from a much more cosmopolitan range of Islamic sartorial options. Light cotton robes from Oman, formal collared gowns from Saudi Arabia, hooded jellabiya from Morocco and new types of fashionable Islamic attire manufactured by British Muslim designers catering for niche diaspora markets, such as Lawung ${ }^{10}$ or Al Faizan ${ }^{11}$, were all popular among my respondents. This subtle shift indicates the supplanting of ethnic identities by more global notions of Muslim selfhood. In the British context, this tendency has perhaps been expedited by the 'hyper-diversity' of global cities such as London whose multiple immigration flows allow vibrant intercultural exchange between numerous Muslim ethnic groups jostling in close proximity. ${ }^{12}$

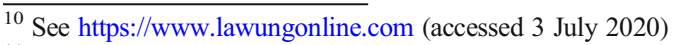

${ }^{11} \mathrm{See}$ https://www.al-faizan.com/ (accessed 3 July 2020)

12 This cultural eclecticism is sometimes mirrored by an intellectual cosmopolitanism. For instance, during my fieldwork in Bulgaria, I noticed that the amir of our British TJ group would frequently listen to Islamic lectures on his headphones via an MP4 player before sleeping. Upon enquiry, he explained he was listening to the American scholar Shaykh Hamza Yusuf who had considerably shaped his understanding of Islam over the years.
} 
In contrast to a reductionist set of binaries which conceptualise identity in either/or terms then, the empirical reality of British Muslim identity seems to be more accurately represented as a hybridised mélange or a disorderly bricolage of myriad identity markers manifested distinctly under the pressure of different situations (Mandaville 2001, pp. 90-101). While the salience of religion has clearly been foregrounded for many second-generation British Muslims - particularly those affiliated with revivalist movements such as the Tablighi Jama'at - I would argue that their lived experiences continue to be mediated by a confluence of ethnic ancestry as well as the socio-cultural contexts in which their secondary socialisations occur. In respect of the latter, such ubiquitous aspects of the British collective conscience as J.K. Rowling's series of Harry Potter books, and the related films, contribute to shaping the worldview of young Muslims. This was memorably driven home to me during 10 days of fieldwork I conducted with teenage college students on a TJ khuruj to Bradford during their 2014 summer holidays. The khuruj started at the movement's European headquarters in Dewsbury, which provided many of the youth with the opportunity to visit this landmark site and interact with the various elders who manage its day-to-day affairs for the first time. During the subsequent stay in several Bradford mosques, they humorously compared these elders with various teachers at Hogwarts School of Witchcraft and Wizardry. Hafiz Patel, the white-bearded spiritual figurehead of TJ in the West, was unanimously declared to be Professor Dumbledore - an unqualified force of goodness, wisdom and benevolence. Another Dewsbury elder, known for his strictness, was less graciously referred to as Severus Snape while a particularly hairy one was assigned the nickname of Rubeus Hagrid.

Hybridisation, however, is a two-way street. While the wider British collective conscience continually informs Muslim socialisation experiences as a kind of background chorus across the various sub-worlds and generations, it remains, in line with the key principles of Berger and Luckmann's tripartite paradigm, simultaneously and continually produced by human activity in toto. Consequently, the production and sedimentation of ethno-religious meanings into a distinctive subculture, while inevitably absorbing into itself elements of the wider collective conscience, simultaneously impacts the cultural contours of that same collective conscience. Returning again to the motif of food as an important marker of cultural identity, then Foreign Secretary Robin Cook's comments about chicken tikka masala (presumably, mostly halal) in a 2001 public speech are telling:

Chicken Tikka Massala is now a true British national dish, not only because it is the most popular, but because it is a perfect illustration of the way Britain absorbs and adapts external influences. Chicken Tikka is an Indian dish. The Massala sauce was added to satisfy the desire of British people to have their meat served in gravy. ${ }^{13}$

\footnotetext{
${ }^{13}$ See https://www.theguardian.com/world/2001/apr/19/race.britishidentity (accessed 3 July 2020). See also Penn and Lambert (2009, p. 33).
} 


\section{Manning the fort: fundamental British values and the social construction of nation}

In situations in which the collective conscience is weak - as I have argued it is in contemporary Britain given the twin fragmentation of religious and national identities - its homogenising capacity is diminished as pockets of counter-cultural meaning are able to establish themselves and fulfil the basic, essential function of anomalistic primary socialisation with relative ease. In this regard, the IpsosMORI (2007, p. 7) survey cited earlier notes that '...it is this fuzzy quality of Britishness that has so far allowed it to encompass the national [Welsh, Scottish, Irish] and ethnic identities by default rather than design.' This, of course, raises issues of 'social cohesion' exacerbated, for Muslims, by acts of terrorist violence committed in the name of Islam. In particular, significant consternation has been caused by the fact that three of the four 7/7 suicide bombers were British-born, and that the group's ringleader Mohammad Sidique Khan was ostensibly well-integrated into society, along with the more recent phenomenon of British-born youth leaving Britain to join ISIS (Ahmad 2017). For many, 2016 was a watershed year with Donald Trump's election in the USA and Britain's historic Brexit decision reflecting rising nativist sentiment across Europe and America. In 2011, then Prime Minister David Cameron popularised the term 'muscular liberalism' during a well-publicised speech at an international security conference in Munich:

In the UK, some young men find it hard to identify with the traditional Islam practiced at home by their parents, whose customs can seem staid when transplanted to modern Western countries. But these young men also find it hard to identify with Britain too, because we have allowed the weakening of our collective identity. Under the doctrine of state multiculturalism, we have encouraged different cultures to live separate lives, apart from each other and apart from the mainstream. We've failed to provide a vision of society to which they feel they want to belong. (excerpt from speech by David Cameron $^{14}$; see also Heath and Demireva 2014)

Cameron's 'muscular liberalism' has subsequently been operationalised in several ways. In November 2014, the Department for Education published guidance on promoting 'Fundamental British Values' in schools - derived from the 2011 Prevent Strategy and in apparent response to the 'Trojan Horse' outcry - to be monitored through the SMSC (spiritual, moral, social and cultural) element of Ofsted inspections; while schools were previously expected to simply respect these values, they were now required to actively promote and demonstrably embed them in pupils' learning experiences. ${ }^{15}$ In December 2016, Dame Louise Casey

\footnotetext{
${ }^{14}$ For a full transcript of the speech, see https:/www.gov.uk/government/speeches/pms-speech-at-munichsecurity-conference (accessed 3 July 2020)

${ }^{15}$ See https://www.gov.uk/government/news/guidance-on-promoting-british-values-in-schools-published (accessed 3 July 2020)

${ }^{0} \mathrm{https}$ //www.gov.uk/government/publications/the-casey-review-a-review-into-opportunity-and-integration (accessed 3 July 2020)

0 https://www.gov.uk/government/consultations/integrated-communities-strategy-green-paper; https:/www. gov.uk/government/publications/integrated-communities-action-plan (accessed 3 July 2020)
} 
published the findings of her review, commissioned a year earlier by the Prime Minister and Home Secretary, 'into integration and opportunity in our most isolated and deprived communities. ${ }^{, 16}$ Her report was followed by an Integrated Communities Strategy Green Paper in March 2018 whose proposals led to an Action Plan published in February 2019 that 'sets out the government's next steps for building strong integrated communities ... where people - whatever their background - live, work, learn and socialise together... . ${ }^{17}$ At the core of these developments, it seems, lies an impulse to provide a set of values that function, in a Durkheimian sense, as a 'social glue' that binds citizens together; to weld, out of an increasingly heterogeneous assortment of source materials, a unified sense of nation.

Kwame Gyekye (1997), reflecting on the challenges faced by postcolonial Africans grasping the nettle of self-determination, usefully distinguishes between different conceptions of nation. First, he proposes, a nation may be conceived of as a relatively homogenous ethnocultural community bound by a common language and history whose members share strong feelings of cohesion, solidarity and belonging. This he terms $\mathrm{N}_{1}$, a simple essentially sociocultural phenomenon. $\mathrm{N}_{2}$, on the other hand, refers to a more complex political entity, the multinational state, whose populace consists of numerous $\mathrm{N}_{1} \mathrm{~s}$ bound by a sovereign authority. The basic social goal of $\mathrm{N}_{2}$, claims Gyekye (1997), is to weld the constituent $\mathrm{N}_{1} \mathrm{~s}$ together under a shared rubric of national identity, an ideal attempted through the process of nation-building: 'Nation-building is thus a conscious and purposive attempt to bring different peoples together to think, act, and live as if they were one people belonging to one large ethnocultural community, that is, as if they belonged to an $\mathrm{N}_{1}$ ' (85). Nationbuilding thus emerges as a type of social engineering that depends upon the concoction — or, indeed, the 'imagination' (Anderson 1983) — of a unified set of values which ostensibly capture the autochthonous cultural essence of the majority group inhabiting the geographic boundaries of the nation state. Successful nation-building, for Gyekye (1997), occurs when the constituent groups of the bounded territory transfer their loyalties and commitments from the particular to the whole, or from the specificities of their ethnocultural group to the generality of the state. This happens through the horizontalization of the socio-cultural features of $\mathrm{N}_{1}$ across the political entity of $\mathrm{N}_{2}$ to form a new entity, $\mathrm{N}_{3}$. While easy to conceptualise as a normative ideal, the tangible achievement of $\mathrm{N}_{3}$ in history has been far more elusive: "The conquerors who shepherded different nationalities into nation-states failed to realize that it is one thing to make Ghana or Kenya or Yugoslavia; it is quite another to make Ghanaians or Kenyans or Yugoslavs' (82).

Britain's colonial adventures through much of the nineteenth and twentieth centuries were premised upon a strong, assured sense of self-fuelled by the technological achievements of the Industrial Revolution and an unabashed moral superiority evinced, for example, in Rudyard Kipling's 'The White Man's Burden' - that endured even in foreign climes. The subsequent disintegration of empire allied with pervasive processes of secularisation,

\footnotetext{
$\overline{16} \mathrm{https} / /$ www.gov.uk/government/publications/the-casey-review-a-review-into-opportunity-and-integration (accessed 3 July 2020)

17 https://www.gov.uk/government/consultations/integrated-communities-strategy-green-paper; https:// www.gov.uk/government/publications/integrated-communities-action-plan (accessed 3 July 2020)
} 
globalisation and a range of post-war immigration flows have, as we have seen, substantially altered her national identity and relationship with Christianity. The establishment of numerous minority groups on her shores - $\mathrm{N}_{1} \mathrm{~s}$ who look, dress, eat, speak, pray and frequently appear to think and feel differently to the majority population (Timol 2018)- have obliged the administrators of the $\mathrm{N}_{2}$ political apparatus to confront squarely the quandary of "nationbuilding' previously left as a legacy for decolonised nations. Thus, the social construction of nation becomes a political imperative. Returning to Berger and Luckmann's tripartite model, processes of externalisation and objectivation are activated as Whitehall officials determine the presumed essence of British identity - notably, lacking any reference to her longstanding Christian heritage — codified as a set of 'Fundamental British Values'. ${ }^{18}$ For Anderson, a latent sense of nationalism can be ignited with the convergence of two factors - the presence of a clear threat, such as that experienced during World War 2, or when the sentiments of the populace are manipulated by the state through the vehicle of mass media, as witnessed during the Falklands War (Anderson and Ali 1991). Both factors can today be discerned in the increasing conflation of counter-terrorism measures with the integration agenda, as aptly demonstrated in the so-called Trojan Horse furore (Miah 2017). For Gellner (1983), the machinery of state education enables the crucial dissemination of the cultural idioms of national identity on a mass scale; citizens are thus produced as such idioms are consciously embedded in core institutional repositories of the collective conscience and internalised by pupils through processes of secondary socialisation. Yet, as we have seen, the contents of secondary socialisation are internalised into consciousness far less effectively than the formative substance of primary socialisation (Berger and Luckmann 1966, pp. 161-165). Put differently, Ofsted will always struggle to replace the role of the parent.

\section{Conclusion}

In 1998, the International Sociological Association ranked The Social Construction of Reality: A Treatise in the Sociology of Knowledge by Peter Berger and Thomas Luckmann as the fifth most important sociological book of the twentieth century. ${ }^{19}$ More recently, Knott and Lee (2017, p. 13) in their wide-ranging research synthesis of over a hundred books and articles on The Family and Ideological Transmission found that 'Much latetwentieth century work on social, political and religious transmission and learning drew on

\footnotetext{
18 Government guidance states that both independent and state-maintained schools '... have a responsibility to 'actively promote' the fundamental British values of democracy, the rule of law, individual liberty, and mutual respect and tolerance of those with different faiths and beliefs' (see https://www.gov.uk/government/ news/guidance-on-promoting-british-values-in-schools-published. accessed 3 July 2020). The Church of England, reportedly, decried the omission of such Christian virtues as 'love thy neighbour' from this roster (see for instance https://www.secularism.org.uk/news/2014/11/promotion-of-british-values-undermineschristian-teaching-says-church-of-england\%2D\%2Dnss-responds, accessed 3 July 2020). Interestingly, references to Christianity were similarly excised during the framing of the European Constitution at the start of this century: 'Though many wished to include at least a passing nod to the Christian heritage [of European values and civilisation], others strenuously resisted even such an acknowledgement ... The 70,000 words of this prolix document thus fail to include a single specific reference to Christianity' (Jenkins 2007, pp. 38-39).

${ }^{19} \mathrm{See}$ http://www.isa-sociology.org/en/about-isa/history-of-isa/books-of-the-xx-century/ (accessed 3 July 2020).
} 
Berger and Luckmann's theorisation of socialisation...'. Despite the enduring value of this work, its potential to theorise the socialisation experiences of immigrants and their offspring appears to have remained largely untapped. This article has been a first step in this direction, with a specific focus on Muslim faith identities mediated through the British branch of the international revivalist movement the Tablighi Jama'at.

Robinson (1988, pp. 17-18) has pointed out the irony that 'Islamic ideas, developed by movements which aimed to escape the consequences of British rule and Western civilisation, have since Independence been carried by these movements to the very heart of Britain and the West.' Allied with the post-WW2 immigration drive from South Asia, the Tablighi Jama'at provides an apt illustration of this. While the movement played an important role in consolidating the faith identity of many firstgeneration South Asian migrants, by functioning as a religious anchor in the new context and catalysing a national process of mosque-building, this paper has principally explored the cultural evolution of the movement as it has been increasingly appropriated by a generation of British-born activists whose primary and secondary socialisation experiences unfold in the UK. In doing so, it has triangulated Berger and Luckmann's theory of socialisation with a tripartite model of British Muslim identity proposed by Ron Geaves.

In line with much extant work on Muslim identity in the West, the findings recognise the increasing salience of religion for a diaspora-born generation particularly those affiliated with revivalist movements. ${ }^{20}$ Specifically, they depict the TJ activity of khuruj-regular mosque-based retreats - as an effective arena of 'secondary socialisation' where the sociological mechanics of 'intrareligious conversion' are activated. Unlike the case of non-Muslim conversion to Islam, however, the paper argues that the Tablighi Jama'at relies on rekindling in neophyte consciousness an emotional attachment to core tenets of the Islamic faith first internalised during the formative experience of childhood primary socialisation. While a level of desocialisation from the norms of mainstream society is intrinsic to this process, exemplified through various changes in lifestyle or dress code, the paper has simultaneously characterised diaspora religiosity as a cultural mélange given the ongoing influence of both ethnic ancestry and the wider British collective conscience.

In this, the findings nuance a frequent trope about revivalist movements in contemporary Islam. To take an influential example, Roy's (2004) thesis on Globalised Islam argues that 'neo-fundamentalist' movements such as TJ replicate, through processes of deculturation and deterritorialisation, the modalities of globalisation to generate individuated forms of religious praxis rooted in an idealised prophetic prototype. They therefore quest for a pristine Islam shorn of cultural accretions which hearkens back to the golden age of the Prophet and his Companions. Certainly, in some Muslim-majority contexts such as The Gambia, the Tablighi Jama'at has functioned as a form of reformist Islam (sila kutoo) challenging the authority of marabouts and the time-honoured legitimacy of local Islamic customs (sila keebaa); a debate, as Janson (2014) has shown,

\footnotetext{
${ }^{20}$ This should not obscure obverse trends of secularisation and outright apostasy which simultaneously punctuate the landscape of British Islam with increasing prominence (see, for example, Orenstein and Weismann 2016 or Cottee 2015).
} 
often hammered out on the anvil of intergenerational conflict. Yet, this reorientation to a sacred past does not, indeed cannot, take place in a social vacuum. By focussing on the cultural embodiments of Tablighi activism in the largely South Asian minority context of the UK, this paper has argued for a fundamental continuity of identity, even as the individual undergoes multiple resocialisations in different sub-worlds over a biographical life course. What emerges is a hybridised bricolage that draws simultaneously on Geaves' constitutive components of British Muslim identity-religion, ethnicity and nationality - and which reveals the limitations of such blanket assertions as "The Tablighi behave in the same way whatever the cultural and sociological environment, as if they were on an isolated planet' (Roy 2004, p. 288). ${ }^{21}$

Religion, furthermore, has never existed as a set of disembodied ideals but - in line with core principles of Berger and Luckmann's tripartite framework-depends for its survival upon externalisation and objectivation; that is the continual outpouring of meanings into the world which reify over time into habits, institutions, traditions and culture. To express this differently: the lived enaction of the metaphysical must always be grounded in the cultural given that human beings inhabit space and time in bodies that are continually subject to processes of socialisation.

The core philosophical substratum of Berger and Luckmann's sociology of knowledge lies in the proposition that the human being is essentially a biological organism upon which processes of socialisation operate. Emerging into the world tabula rasa, the meaningsystems he embraces as his own are actually no more than contingent chimeras that can be bent to the will of political expediency. ${ }^{22}$ In situations of cognitive combat then, assert Berger and Luckmann (1966, p. 137), the social construction of reality may well be determined by a broader power dynamic: 'In other words, definitions of reality may be enforced by the police ... power in society includes the power to determine decisive socialization processes and, therefore, the power to produce reality'. It is in this context, I have argued, that recent attempts of the British government to promulgate a set of

\footnotetext{
${ }^{21}$ Despite a basic uniformity of method, the Tablighi Jama' at has, in fact, proved remarkably adept at adapting to myriad local cultures. Consider, for example Noor's (2009, p. 48) assessment of its indigenisation in Indonesia: 'What began as a South Asian movement with a distinctive South Asian flavour and feel to it has now transformed itself into a localized mode of normative religiosity that finds adherence and support from the local population of Java ... Unencumbered by ethnic and cultural attachments or the need to retain its South Asian identity, the Tablighi has managed to spread itself from India to Europe, Africa, the Arab world and Asia while localizing itself in each new context it finds itself in.'

${ }^{22}$ Such a perspective, of course, flies in the face of traditional theological understandings of the human creature rooted in the concepts of original sin (Christianity), reincarnation (Buddhism) or the fitra (Islam). From the perspective of the sociology of knowledge, such conceptualisations must be bracketed as they are not amenable to empirical investigation (cf. Berger's (1967, p. 100) concept of 'methodological atheism' but also its critique by Porpora (2006)). Interestingly, however, the power of socialisation to construct worlds of meaning entirely taken-for-granted in subjective consciousness was intuited by the celebrated Muslim theologian Abu Hamid al-Ghazali in his intellectual autobiography 900 years ago: '...the fetters of servile conformism fell away from me, and inherited beliefs lost their hold on me, when I was still quite young. For I saw that the children of Christians always grew up embracing Christianity, and the children of Jews always grew up adhering to Judaism, and the children of Muslims always grew up following the religion of Islam. I also heard the tradition related from the Apostle of God - God's blessing and peace be upon him! - in which he said: 'Every infant is born endowed with the fitra then his parents make him Jew or Christian or Magian.' Consequently, I felt an inner urge to seek the true meaning of the original fitra, and the true meanings of the beliefs arising through slavish aping of parents and teachers' (McCarthy 2000, pp. 19-20). Ibn Tufayl's exploration of this theme in his classic work Hayy ibn Yaqzan is also relevant (Goodman 2009 [2003]).
} 
fundamental British values through schools should be understood. Drawing on the work of Kwame Gyekye, I have suggested that - especially in light of weakened national and religious identities intensified by multiple immigration flows - the quandary of 'nationbuilding' previously left as a legacy for decolonised nations has now become a peculiarly home-grown problem. A myth of fundamentalist Britishness thus emerges as an anchor of identity which mirrors, in several important ways, the myth of pure Islam to which revivalist groups ostensibly aspire.

Such myths however are always unattainable in the concrete matrixes of real life. This article has argued for example that the subtle residues of ethnic culture, rooted in consciousness during the powerful formative experience of primary socialisation, cannot easily be disavowed but continue to manifest themselves in such foundational impulses of the diaspora-born Muslim as the proclivities of the palate, an instinctive gesture of deference offered when greeting a family elder or in failing a hypothetical version of Lord Tebbit's 'cricket test' by supporting Pakistan over Saudi Arabia. Further, the religiosity of a diaspora-born generation cannot but develop symbiotically or dialectically - depending on the particular tendency — with the broader social milieu in which it is actualised. Consequently, new forms of hybridised Islam (and, indeed, national culture) emerge that draw upon the cultural repertoires of the social arenas in which the British-born generation's secondary socialisations occur, not least the wider cultural emphasis on individualisation noted earlier. Several publications exemplify this shift including, notably, Janmohamed's (2016) vivacious capturing of 'Generation M', Imtiaz's (2011) ruminations on 'the Muslim condition in the West' and Herding's (2013) descriptions of an emergent 'conservative avant-garde' among Islamic youth cultures in France, Britain and Germany. While this paper has focussed on the experiences of British-born Tablighis, I would maintain that the findings transcend this immediate empirical setting, and in line with this broader corpus of literature, reflect processes of cultural indigenisation operative in British Islam more generally.

Funding I wish to record my gratitude to the Jameel Scholarship Programme whose generous funding made possible the research upon which this paper is based.

Open Access This article is licensed under a Creative Commons Attribution 4.0 International License, which permits use, sharing, adaptation, distribution and reproduction in any medium or format, as long as you give appropriate credit to the original author(s) and the source, provide a link to the Creative Commons licence, and indicate if changes were made. The images or other third party material in this article are included in the article's Creative Commons licence, unless indicated otherwise in a credit line to the material. If material is not included in the article's Creative Commons licence and your intended use is not permitted by statutory regulation or exceeds the permitted use, you will need to obtain permission directly from the copyright holder. To view a copy of this licence, visit http://creativecommons.org/licenses/by/4.0/.

\section{References}

Abd-allah, F. U. (2004). Islam and the cultural imperative. Chicago: Nawawi Foundation.

Ahmad, F. (2017). Do young British Muslim women need rescuing? In S. Hamid (Ed.), Young British Muslims: between rhetoric and realities. Abingdon: Routledge.

al-Hajj, M., \& Yusuf, H. (2001). Fatwa concerning the obligation of following rightly guided scholars. Hayward, CA: Zaytuna Institute. 
Alba, R. (2005). Bright vs. blurred boundaries: Second-generation assimilation and exclusion in France, Germany, and the United States. Ethnic and Racial Studies, 28(1), 20-49. https://doi.org/10.1080/ 0141987042000280003 .

Anderson, B. (1983). Imagined Communities: Reflections on the Origin and Spread of Nationalism. London: Verso.

Anderson, Benedict, interviewd by Tariq Ali. (1991). The World Today with Tariq Ali: Imagined Communities - On British Nationalism. https://www.youtube.com/watch?v=15nqjGCAqd4 (16m.40s; accessed 3 July 2020): Telesur Videos (https:/videosenglish.telesurtv.net/video/504840/the-worldtoday-504840/).

Ansari, H. (2004). The infidel within: Muslims in Britain since 1800. London: C. Hurst \& Co. (Publishers) Ltd..

Anwar, M. (1979). The myth of return: Pakistanis in Britain. London: Heinemann Educational Books Ltd..

Bagguley, P., \& Hussain, Y. (2005). Flying the flag for England? Citizenship, religion and cultural identity among British Pakistani Muslims. In T. Abbas (Ed.), Muslim Britain: Communities Under Pressure. London: Zed Books.

Barber, B. (2011 [1995]). Jihad Vs McWorld. London: Corgi.

Berger, P., \& Luckmann, T. (1966). The social construction of reality: a treatise in the sociology of knowledge. London: Penguin Books.

Berger, P. L. (1967). The Sacred Canopy: Elements of a Sociological Theory of Religion. New York: Doubleday.

Birkelbach, K., \& Meulemann, H. (2013). Christian socialization during youth and Christian convictions from early to late midlife. Journal of Religion in Europe, 6(4), 399-427. https://doi.org/10.1163/1874892900604001 .

Brown, C. G. (2001). The death of Christian Britain: understanding secularisation 1800-2000. Abingdon: Routledge.

Brown, J. M. (2006). Global South Asians: introducing the modern diaspora. Cambridge: Cambridge University Press.

Bruce, S. (2002). God is dead: secularization in the West. Oxford: Blackwell Publishers Ltd..

Butt, J. (2020). A Talib's tale: the life and times of a Pashtoon Englishman. New Delhi: Penguin.

Casanova, J. (1994). Public religions in the modern world. Chicago and London: The University of Chicago Press.

Cornwall, M. (1988). The influence of three agents of religious socialization: family, church, and peers. In D. L. Thomas (Ed.), The Religion and Family Connection: Social Science Perspectives. Provo, UT: Religious Studies Center, Brigham Young University.

Cottee, S. (2015). The apostates: when Muslims leave Islam. London: C. Hurst \& Co..

Davie, G. (1994). Religion in Britain since 1945: believing without belonging. Oxford: Blackwell.

Davie, G. (2000). Religion in modern Europe: a memory mutates. Oxford: Oxford University Press.

Davie, G. (2015). Religion in Britain: a persistent paradox. Chichester: Blackwell Publishers.

Dawkins, R. (2006). The God delusion. London: Transworld Publishers.

DeHanas, D. N. (2016). London youth, religion, and politics: engagement and activism from Brixton to Brick Lane. Oxford: Oxford University Press.

Duderija, A. (2008). Factors determining religious identity construction among Western-born Muslims: towards a theoretical framework. Journal of Muslim Minority Affairs, 28(3), 371-400. https://doi.org/ $10.1080 / 13602000802548003$.

Durkheim, E. (1984 [1933]). The division of labor in society. New York: The Free Press, Simon \& Schuster Inc..

Fox, K. (2004). Watching the English: the hidden rules of English behaviour. London: Hodder and Stoughton Ltd..

Geaves, R. (1996). Sectarian influences within Islam in Britain with reference to the concepts of 'ummah' and 'community'. Community Religions Project: University of Leeds.

Geaves, R. (2010). Islam in Victorian Britain: the life and times of Abdullah Quilliam. Leicester: Kube Publishing.

Gellner, E. (1983). Nations and nationalism. Oxford: Blackwell.

Gilham, J. (2014). Loyal enemies: British converts to Islam, 1850-1950. London: C Hurst \& Co (Publishers) Ltd.

Gilliat-Ray, S. (2010). Muslims in Britain: An introduction. Cambridge: Cambridge University Press.

Goodman, L. E. (2009 [2003]). Ibn Tufayl's Hayy Ibn Yaqzan: a philosophical tale. Chicago: The University of Chicago Press. 
Gyekye, K. (1997). Tradition and modernity: philosophical reflections on the African experience. New York: Oxford University Press.

Hamid, S. (2015). Sufis, Salafis and Islamists: the contested ground of British Islamic activism. London: I.B.Tauris \& Co Ltd..

Hayes, B. C., \& Pittelkow, Y. (1993). Religious belief, transmission, and the family: an Australian study. Journal of Marriage and Family, 55(3), 755-766. https://doi.org/10.2307/353355.

Heath, A., \& Demireva, N. (2014). Has multiculturalism failed in Britain? Ethnic and Racial Studies, 37(1), 161-180. https://doi.org/10.1080/01419870.2013.808754.

Herberg, W. (1955). Protestant-Catholic-Jew: An essay in American Religious Sociology. Garden City, New York: Doubleday \& Company Inc.

Herding, M. (2013). Inventing the Muslim cool: Islamic youth culture in Western Europe. Bielefeld: Transcript Verlag.

Hirsch, A. (2018). Brit(ish): on race, identity and belonging. London: Vintage.

Hitchens, C. (2007). God is not great: how religion poisons everything. London: Atlantic Books (Kindle Edition).

Imtiaz, A. (2011). Wandering lonely in a crowd: reflections on the Muslim condition in the West. Markfield: Kube Publishing Ltd..

Inge, A. (2017). The making of a Salafi Muslim woman: paths to conversion. Oxford: Oxford University Press.

IpsosMORI. (2007). Young people and British identity. London: Ipsos MORI / The Camelot Foundation.

Jacobson, J. (1997). Religion and ethnicity: Dual and alternative sources of identity among young British Pakistanis. Ethnic and Racial Studies, 20(2), 238-256. https://doi.org/10.1080/01419870.1997.9993960.

Janmohamed, S. (2016). Generation M: young Muslims changing the world. London: I.B. Tauris.

Janson, M. (2014). Islam, youth and modernity in the Gambia: the Tablighi Jama'at. Cambridge: Cambridge University Press.

Jawad, H. A. (2012). Towards building a British Islam: new Muslims' perspectives. London: Continuum.

Jenkins, P. (2007). God's continent: Christianity, Islam and Europe's religious crisis. Oxford: Oxford University Press.

Knott, K., \& Lee, B. (2017). Ideological transmission I: the family and ideological transmission. CREST: Lancaster.

Lewis, P. (2007). Young, British and Muslim. London: Continuum International Publishing Group.

Mandaville, P. (2001). Transnational Muslim politics: reimagining the umma. London: Routledge.

McCarthy, R. J. T. (2000). Al-Ghazali's path to Sufism: his deliverance from error - al-Munqidh min al-Dalal. Louisville: Fons Vitae.

McGuckin, C., Lewis, C., Cruise, S., \& Fearn, M. (2009). The influence of parents on religious socialisation. In H.-G. Ziebertz, W. K. Kay, \& U. Riegel (Eds.), Youth in Europe III: An International Empirical Study of Religion on Life Orientation. Berlin: Lit Verlag.

Miah, S. (2017). Muslims, schooling and security: Trojan Horse, prevent and racial politics. UK: Palgrave Macmillan.

Moreton, C. (2010). Is God still an Englishman? London: Little, Brown (Hachette).

Morrison, K. (1995). Marx, Durkheim, Weber: formations of modern social thought. London: SAGE Publications Ltd..

Mustafa, Asma. 2015. Identity and political participation among young British Muslims: believing and belonging basingstoke: Palgrave Macmillan.

Noor, F. A. (2009). The spread of the Tablighi Jama'at across Western, Central and Eastern Java and the role of the Indian Muslim diaspora. Working Paper 175 (pp. 1-77). Singapore: S. Rajaratnam School of International Studies.

Orenstein, Z., \& Weismann, I. (2016). Neither Muslim nor other: British secular Muslims. Islam and Christian-Muslim Relations, 27(4), 379-395. https://doi.org/10.1080/09596410.2016.1148892.

Özdikmenli-Demir, G., \& Şahin-Kütük, B. (2012). The role of parents, siblings, peers, relatives and other agents in Turkish-Muslim emerging adults' religious socializations. Archive for the Psychology of Religion, 34(3), 363-396. https://doi.org/10.1163/15736121-12341250.

Parekh, B. (2008). European Liberalism and 'The Muslim Question'. ISIM Paper 9 / Leiden: Amsterdam University Press.

Penn, R., \& Lambert, P. (2009). Children of international migrants in Europe: comparative perspectives. Basingstoke: Palgrave Macmillan UK.

Porpora, D. V. (2006). Methodological atheism, methodological agnosticism and religious experience. Journal for the Theory of Social Behaviour, 36(1), 57-75. 
Robins, K. (1991). Tradition and translation: national culture in its global context. In J. Croner \& S. Harvey (Eds.), Enterprise and Heritage: crosscurrents of National Culture. London: Routledge.

Robinson, F. (1988). Varieties of South Asian Islam. Coventry: CRER/ESRC Research Papers in Ethnic Relations.

Roy, O. (2004). Globalised Islam: the search for a new Ummah. London: Hurst \& Company.

Saeed, A. (2017). Digital orientalism: Muslim youth, Islamophobia and online racism. In S. Hamid (Ed.), Young British Muslims: between rhetoric and realities. Abingdon: Routledge.

Sardar, Z. (2008). Balti Britain: a provocative journey through Asian Britain. London: Granta Publications.

Scott, J. (2014). Oxford dictionary of sociology. In. Oxford: Oxford University Press.

Scourfield, J., Gilliat-Ray, S., Khan, A., \& Otri, S. (2013). Muslim childhood: religious nurture in a European context. Oxford: Oxford University Press.

Sikand, Y. S. (1998). The origins and growth of the Tablighi Jamaat in Britain. Islam and Christian-Muslim Relations, 9(2), 171-192. https://doi.org/10.1080/09596419808721147.

Spencer, N. (2010). Without God and country, how will the young flourish? In The Guardian.

Stott, G. N. (1988). Familial influence on religious involvement. In D. L. Thomas (Ed.), The Religion and Family Connection: Social Science Perspectives. Provo, UT: Religious Studies Center, Brigham Young University.

Timol, R. (2015). Religious travel and the Tablighī Jamā'at: modalities of expansion in Britain and beyond. In Y. Suleiman (Ed.), Muslims in the UK and Europe I. Cambridge: Centre of Islamic Studies, University of Cambridge.

Timol, R. (2018). Islamic revivalism and Europe's Secular 'Sacred Canopy': exploring the debunking capacity of public religion. In: Hjelm, T. (Ed.), Peter L. Berger and the Sociology of Religion: 50 Years after The Sacred Canopy. London: Bloomsbury Academic.

Timol, R. (2019). Tea, chillies and takeaway: what food choices reveal about British Muslim identity. The Conversation: https://theconversation.com/tea-chillies-and-takeaway-what-food-choices-reveal-aboutbritish-muslim-identity-107674. Accessed 3 July 2020.

van de Pol, J., \& van Tubergen, F. (2014). Inheritance of religiosity among Muslim immigrants in a secular society. Review of Religious Research, 56(1), 87-106. https://doi.org/10.1007/s13644-013-0128-z.

Voas, D., \& Fleischmann, F. (2012). Islam moves West: religious change in the first and second generations. Annual Review of Sociology, 38(1), 525-545. https://doi.org/10.1146/annurev-soc-071811-145455.

Werbner, P. (2002). The Migration Process: Capital, Gifts and Offerings among British Pakistanis. Oxford: Berg Publishers.

Woodhead, L. (2016). The rise of "no religion" in Britain: the emergence of a new cultural majority. Journal of the British Academy, 4, 245-261. https://doi.org/10.85871/jba/004.245.

Woodhead, L., \& Heelas, P. (2000). Religion in modern times: an interpretative anthology. In. Oxford: Blackwell Publishers Ltd.

Zebiri, K. (2007). British Muslim converts: choosing alternative lives. Oxford: Oneworld Publications.

Publisher's note Springer Nature remains neutral with regard to jurisdictional claims in published maps and institutional affiliations. 